\title{
Rola aplikacji mobilnych w kształtowaniu współczesnego miasta
}

\section{Role of mobile applications in the shaping of the modern city}

\begin{abstract}
Streszczenie
Aplikacje mobilne pozwalają na zwiększoną interakcję pomiędzy mieszkańcami z miasta a miejscem, w którym żyją. Łatwiejszy dostęp do informacji pozwala ludziom w bardziej dynamiczny sposób reagować na zachodzące w ich otoczeniu zmiany. $Z$ drugiej strony władze miejskie dzięki uzyskanym danym mogą w coraz bardziej racjonalny sposób planować swoje inwestycje i kierować rozwojem miasta. Mają też ułatwioną drogę do komunikowania się ze społeczeństwem i zdobywania informacji zwrotnych. Dzięki urządzeniom mobilnym i zainstalowanym na nich aplikacjom wiele czynności, które jeszcze na początku lat 90. XX wieku wydawały się niemożliwe do realizacji, stało się dostępne z poziomu zwykłego użytkownika telefonu komórkowego. Zastosowanie aplikacji mobilnych widzimy w wielu dziedzinach. Szczególnie ważnymi z perspektywy urbanistyki wydają się transport, ochrona środowiska oraz ochrona zdrowia (ułatwienia dla osób chorych i niepełnosprawnych).
\end{abstract}

\begin{abstract}
Mobile applications enable increased interaction between the residents of a city and the place in which they live. Easier access to information allows people to react to the changes that occur in their environment more dynamically. On the other hand, municipal authorities, thanks to the data that they collect, are able to increase the rationality of the way in which they plan their projects and their city's development. They also have an easier way of communicating with the public, as well as of getting feedback. Thanks to mobile devices and the applications that are installed on them, many activities that were thought to be impossible in the beginning of the 1990's are now accessible at the level of an ordinary cellphone user. We can observe the use of mobile applications in numerous disciplines. From the point of view of urban design, the most important ones are transport, the protection of the environment and healthcare (advantages for sick and disabled persons).
\end{abstract}

Słowa kluczowe: Aplikacje mobilne, Smart City, Internet rzeczy, Miasto Keywords: Mobile applications, Smart City, Internet of Things, the city

Współczesne społeczeństwa dostały na przełomie XX i XXI wieku urządzenia, które umożliwiają przeskok cywilizacyjny w funkcjonowaniu organizmów miejskich. Smartfony - pozwalają na błyskawiczne pozyskiwanie informacji w praktycznie każdym miejscu, dają też szansę na szybkie reagowanie na zaistniałą sytuację, ułatwiają codzienne czynności, pomagają chronić nasze zdrowie i dbać o środowisko. Zmiany, które obserwujemy w ostatnich dwudziestu latach, można nazwać rewolucyjnymi. Według ostatniego raportu serwisu We Are Social "2017 Digital”1 na świecie jest 4,917 miliarda unikalnych użytkowników telefonów komórkowych. Z tej liczby 2,549 miliarda jest użytkownikami społecznych aplikacji mobilnych. W ciągu roku zanotowano tu pięcioprocentowy wzrost użytkowników telefonów komórkowych i aż 30\% wzrost użytkowników social mediów. W Europie na około 839 milionów mieszkańców przypada 1,101 miliarda telefonów, z tego 340 milionów ma zainstalowane aplikacje, które moż-
At the turn of the $\mathrm{XX}$ and $\mathrm{XXI}$ centuries, modern societies were given devices that make it possible for urban organisms to undergo a civilisational leap. Smartphones allow the rapid acquisition of information in practically any place, while also providing the ability to quickly react to a given situation, making everyday activities easier, helping us to protect our health and the environment. the changes that we have been observing for the past twenty years can be called revolutionary. According to the latest report by We Are Social titled "2017 Digital"1 there are 4,917 billion individual cellphone users. 2,549 of these are users of social media mobile applications. Over the course of a year, a five percent increase in the number of cellphone users and a $30 \%$ increase in the amount of social media users has been noted. In Europe, 839 million inhabitants have 1,101 phones, out of which the number of phones with applications that can be considered social media applications is $\mathbf{3 4 0}$ million. In Poland, these 


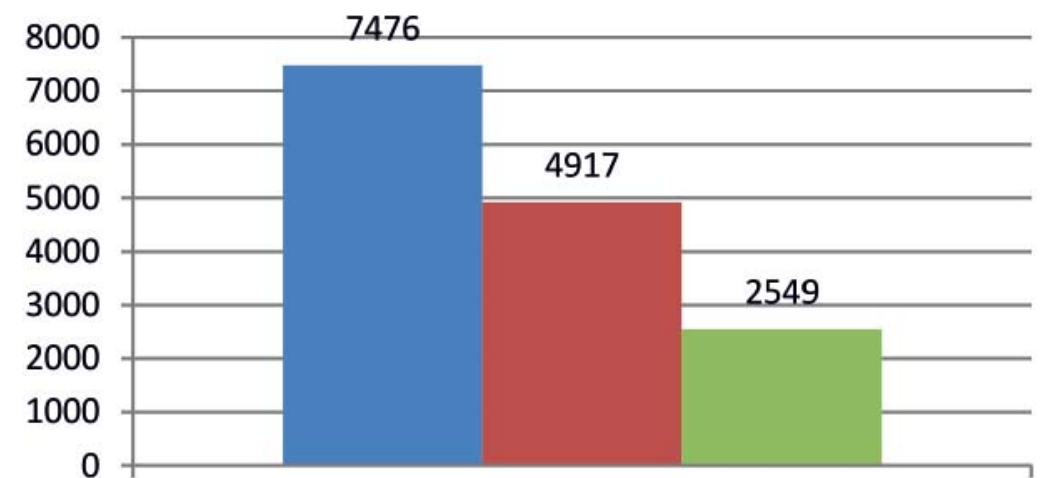

Świat / Global 2016 r.

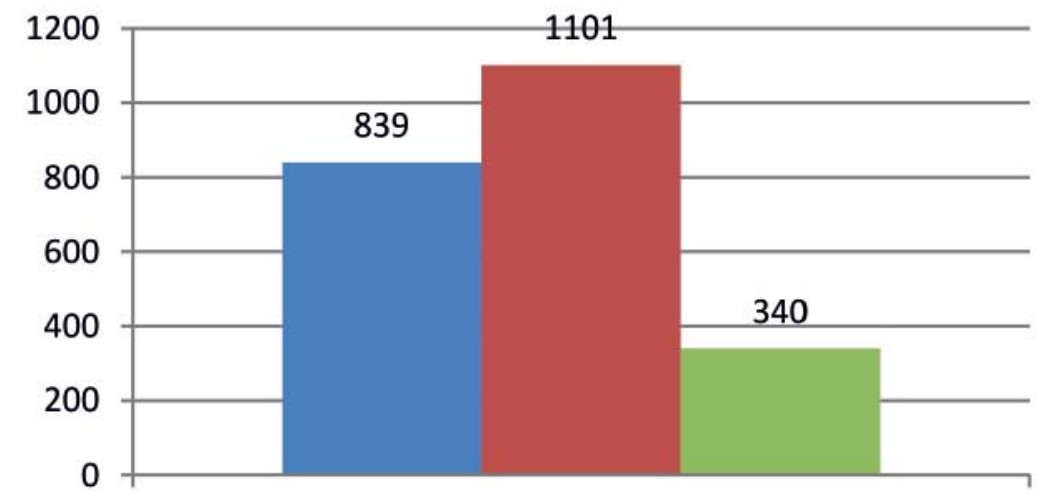

Europa / Europe 2016 r.

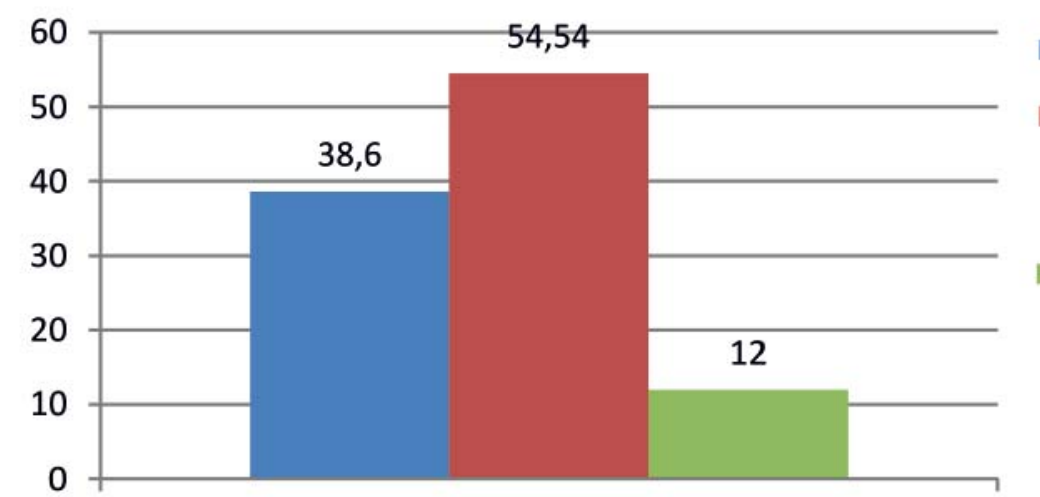

Polska / Poland $2016 \mathrm{r}$.

na zaklasyfikować jako społeczne. W Polsce te liczby wygladają następująco: na około 38,5mln mieszkańców przypada $54,54 \mathrm{mln}$ posiadanych telefonów komórkowych i $12 \mathrm{mln}$ aktywnych użytkowników aplikacji mobilnych'2. Według tego raportu $72 \%$ Polaków używa Internetu z tego $62 \%$ robi to na urządzeniach mobilnych.

W 2016 roku współczynnik urbanizacji Polski wynosił około $60 \%$. Na świecie blisko $55 \%$ populacji mieszka w miastach ${ }^{3}$, a według wszelkich prognoz liczba ta będzie dalej wzrastać. Wartości te pokazują jak wielkie wyzwanie stoi przed administratorami miast, aby ułatwić ludziom funkcjonowanie w nich. Łatwo też, korzystając z efektu skali, zobaczyć jak nawet drobne udogodnienia potrafią przełożyc się na oszczędnośc czasu i pieniędzy, zarowno publicznych jak i prywatnych. Jednak, bez realnych inwestycji w infrastrukturę miejską, nie sprawimy, że miasto nagle zacznie działać bezbłędnie, ale wykorzystanie nowych technologii pozwoli na pewno zoptymalizowac $w$ wielu dziedzinach funkcjonowanie miasta, a co za tym idzie umożliwić lepsze wykorzystanie już istniejących zasobów. Zastosowanie aplikacii mobilnych pozwala na przerzucenie przynajmniej cześciowo kosztów wprowadzenia bardzo nowoczesnych rozwizzań na użytkowników (zakup smartonów - odbioników) oraz na firmy informatyczne/start up'y (aponow

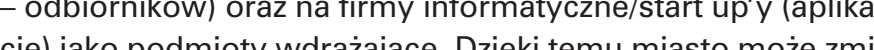
cimoź zmi-

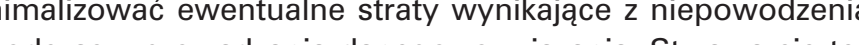
polczas wprowadzana straty wy pole dla parnest

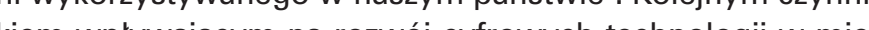

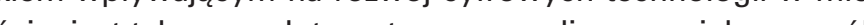
scie, jest tak zwany lin re przedmioto w/rzeczy, kóre gromadzą dane i są podlączone do Internetu. Dane te, przetwazane przez róznego rodzaju aplikacje, dają łatwy dostęp do informacji mieszkańcom oraz władzom miejskim czy też różnego rodzaju przedsiębiorstwom. Co istotne, czynniki te pozwalają na oddziaływanie nie tylko w obrębie ścisłych granicy miejskich, lecz także na sąsiadujacych terenach miejskich lub wiejskich. Rozwiązania takie daja możliwość kreowania rozwiązań aglomeracyjnych. Pozwalaja na pobudzenie aktywności mieszkańców, którzy biorą współ odpowiedzialność za swoje miasto, co opisał Boyd Cohen w swoim artykule jako Smart City 3.0. Autor zauważa tam że oprócz mierzalnych czynników, takich jak np. PKB, równie istotne są kwestie, wmykające się statystkom, jak poczucie zadowolenia czy stopień wpływu na zachodzące w otoczeniu zmiany. Autor stwierdza, że bez udziału miejscowej ludności, wprowadzanie rozwiązań Smart City przypomina kupowani najnowszego gadżetu apple, który koniecznie chcemy mieć, choć nie za bardzo wiemy do czego może nam sie przydaćs. llość aplikacji mobilnych, ułatwiajacych życie mieszkańcom miast i turystom je odwiedzajacym stanowi obszar niemón liwy do opisan w krótkim tekście. Każdego dnia udosteplich

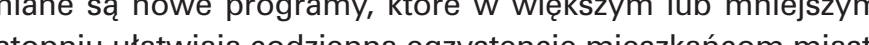

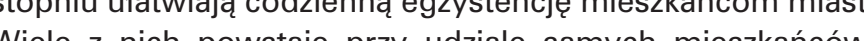

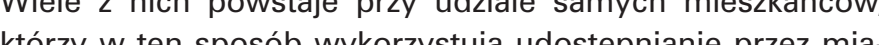
krory w ten sposob wykarzystuja udostepnnie przez mia-

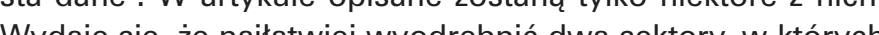
Wydaje się, ze najlatwiej wyodrębnic dwa sektory, w których aplikacje mobilne maja najwększe zastosowanie w miescie a przez to najprzystępniej pozwalają ukazać skalę ich oddziaywania na współczesne "smart city". Są to:

1. Transport.

2. Środowisko i Ochrona Zdrowia (ułatwienia dla osób chorych i niepełnosprawnych).

TRANSPORT

Najbardziej widoczny i odczuwalny wpływ mobilnych aplikacji na funkcjonowanie miasta jesteśmy $w$ stanie zauważyć w sektorze transportu. Zarówno prywatnego jak i publicznego. Każdy mieszkaniec miasta zmaga się codziennie z ulicznym korkami. Systemy sterowania ruchem nie zawsze sa w stanie money, both public and private. However, we will not cause cities to suddenly work flawlessly without investing in urban infrastructure, but the use of many facets of the functioning of a city a result, provide a more efficient use of existing resources. The use of mobile applications allows us to reassign at least some of the costs of introducing cutting edge solutions to the users (the pur(hase of smartphones - receivers) as well as to ing entities. This way a city can minimise potential losses from a failed introduction of a given solution. This also creates a field for private-public partnership, which is still not fully taken advantage of in our country4. Another factor that can impact the
development of digital technologies in a city is the so-called Internet of Things - the larger and larger group of items/things that collect data and that are connected to the Internet. This data, processed by various forms of applications, provides residents, municipal authorities and various businesses with these factors allow influence to be exerted not only in the confines of strict city limits, but also in the neighbouring urban and rural areas. These solutions provide the ability to create agglomeration solutions. They make it possible to stimulate the their city, which has been described by Boyd for hen in his work as Smart City 3.0. The author points out in it that, apart from measurable factors such as GDP, issues that cannot be expressed by statistics are also important, such as the feeling of contentment or the degree of influence on the changes that happen in our surroundings. The author states that introduction of Smart City solutions resembles buying the newest Apple gadget that we desperately want to have, but we do not quite know of what use us it will be ${ }^{5}$.

The amount of mobile applications that make the lives of residents and tourists that visit a city easier
constitutes a field that is impossible to describe in such a short text. New programs that, to a varying extent, make everyday existence easier for the residents of cities are being made available every day. Many of them are being developed with the information that is shared by cities in this manner. This article will describe only some of them. To keep matters simple, two sectors, in which mobile applications see the greatest use within a city and thus make it possible to depict the scale of easiest manner - will be outlined. These are: 1) Transport

) The Environment and Healthcare (conveniences for sick and disabled persons.

TRANSPORT

The most visible and tangible influence of mobile applications on the functioning of a city can be obpublic one.

Every resident of a city must face traffic jams every day. Traffic management systems are not always capable of easing the increasing traffic during rush
hour. Millions spent on roads are not able to immediately make the flow of traffic more efficient 
$\equiv \quad$ Witaj w $\nmid$ skycash

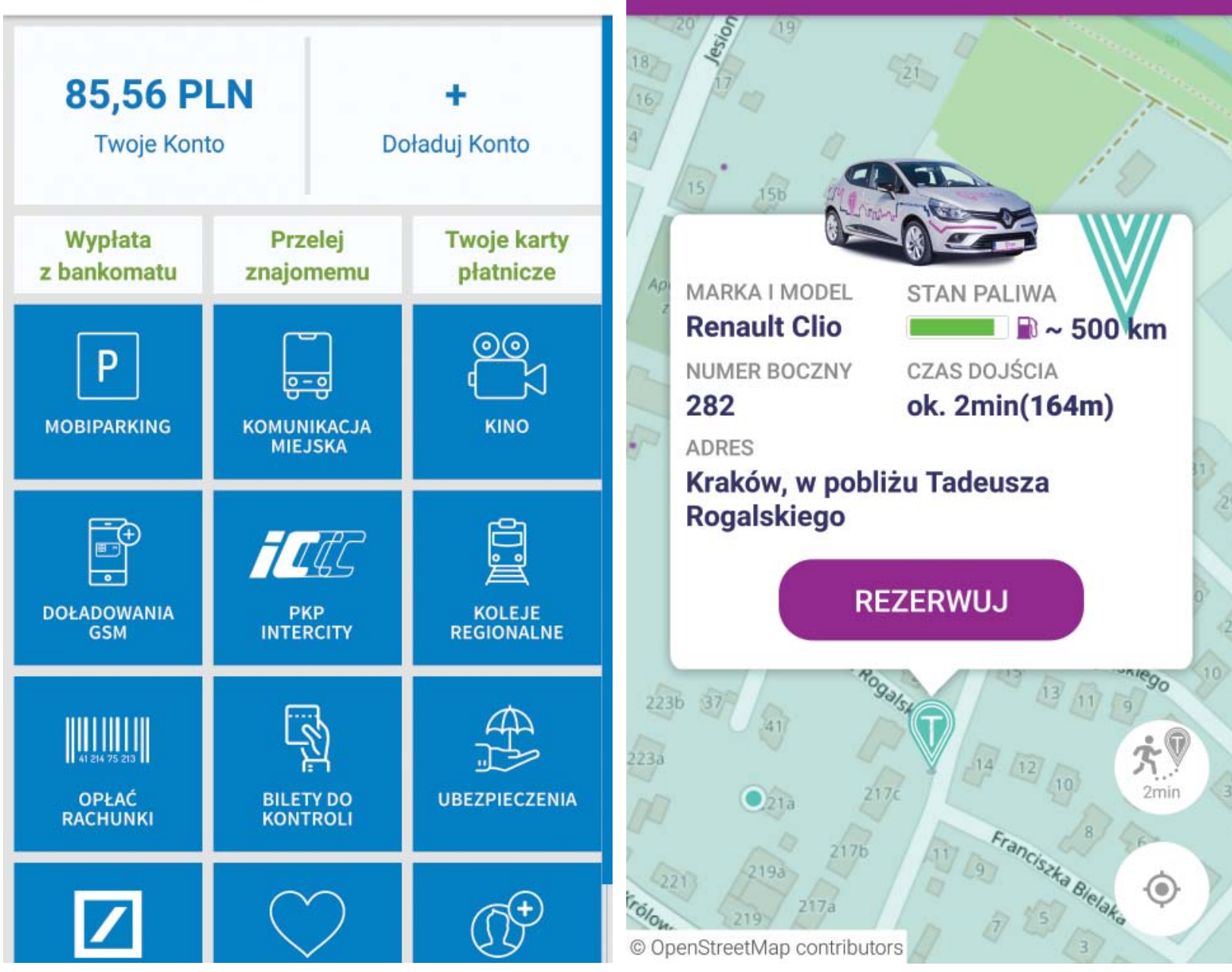

il. 1. Menu gtówne aplikacij Skycash, Foto. Autor / The main menu of the Skycash application. Phot. by the author
il. 2. Aplikacia Traficar - lokalizowanie samochdu. Foto. Autor / The Traficar application

rozładować narastające natężenie ruchu samochodów w godzinach szczytu. Wielomilionowe nakłady na drogi nie od razu usprawniają przepływ pojazdów, często jedynie przesuwając problem o skrzyżowanie dalej, do czasu ukończenia następnego odcinka drogi. Problemem jest też chłonność parkingów w miejscach docelowych, duża cześć ruchu generowana jest przez kierowców szukających miejsc postojowych (wg danych opublikowanych przez władze miejskie Pizy jest to około $30 \%$ całego ruchu w centrum miasta)? . W USA użytkownicy map Google otrzymali do dyspozycji wersję Beta oprogramowania, w ramach zamkniętych testów prowadzonych przez tę korpoację, ktore ułatwic ma wyszukiwanie miejsc postojowych. Kieruje ludzi tam, gdzie system zaobserwował zmniejszony ruch pojazdów (na podstawie śledzenia odbiorników GPS) i spodziewa się, że będą wolne miejsca parkingowe. Po przeanalizowaniu danych, poinformuje nas czy znalezienie miejsca na tym obszarze będzie "łatwe", "średnie" czy „trudne" ${ }^{\text {. }}$. Nad podobnie działającymi aplikacjami pracują takze inne firmy z branzy. often only shifting the problem to the next crossing
until the completion of the next section of the road is complete. The parking capaci eas are also a problem, as a lot of traffic is generated by drivers searching for parking spaces (according to data published by the municipal authoritie Of Pisa they constitute around $30 \%$ of the entire
traffic within the city centre) ${ }^{7}$. In the US the users of Google Maps have been given a beta version of software to perform closed tests performed by search for parking spaces. It directs people to the (on the basis of tracking GPS devices) and where free parking space are to be expected. After analysing this information, it informs us whether the difficulty of finding a parking space within an area will be "easy", "medium" or "hard"s. Other companie cations. IT sector are also working on similar applilike in Pisa, where the city, along with Deutsche
like Telekom and the Kiunsys company that produces the corporation, which is meant to make it easier to
Niektore z nich powoli wchodzą w życie tak, jak to jest w Pizie, czujniki Kiunsys uruchomiło pierwszy Smart Parking. Aplikacja sama zaprowadzi użytkownika do wolnego miejsca postojowego oraz umożliwi wniesienie opłaty. Do tego celu użyto czujników montowanych w asfalcie wielkości portfela, które po najechaniu na nie samochodem sygnalizuia zajecie miesca. Pomyst opierajacy sie na doskonale znanym z galerii handlowych wskazywaniu wolnych miejsc, sygnalizowanych iedlowych wskazzwat wien Dodatkowa funkcia przydatna w szczególności dla turystón. choc docenia ją też niektórzy mieszkańcy, jest możliwość odnalezienia swojego samochodu dzięki lokalizacji poszczególnych miejsc postojowych w aplikacji w smartfonie.

Po dojechaniu na miejsce, kolejnym wyzwaniem jest znalezienie parkometru i opłacenie czasu postoju. Znów z pomoca przychodzą nam aplikacje mobilne np. działający w większości polskich miast Skycash (il.1). Dzięki niej, w latwy sposób opłacimy strefę płatnego parkowania, dodatkowo płacąc dokładnie tyle ile wynosi czas naszego postoju. Za pomoca jednej aplikacji zrobimy to zarówno w Warszawie, Krakowie czy też Wejherowie. Z perspektywy miasta, istotnym czynnikiem jest obniżenie kosztów serwisowania tradycyjnych parkometrów, gdzie często koszt eksploatacji przekracza w pespektywie 10-letniej, koszt zakupu urządzenia. Rozwiązanie to pozwala takze odpowiednim słuzbom na śledzenie realnego sredniego czasu zajmowania miejsc w poszczególnych rejonach strefy płatnego parkowania. Probuje się lepiej wykorzystać posiadaną bazę miejsc parkingowych, np. przez wprowadzenie stanowisk z ograniczonym czasem maksymalnego postoju lub podjęcie decyzji o budowie parkingu podziemnego.

Dodatkowo aplikacje, służące do opłacenia postoju samochodu, często oferuja możliwość zakupu biletu komunikacij miejskiej. Wspomniana aplikacja Skycash oferuje taka ustuge w ponad 40 ośrodkach miejskich na terenie catej Polkk. Dodatkowo użytkownik zapłaci za jej pośrednictwem zo kisk pociag opłaci rachunki czy wykupi ubezpieczenie. 0 za kino, popularność świ sazy blisko $5 \mathrm{mln}$ pobrań ze sklepu Plal je

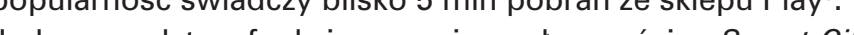
J.0 jest tak zwan ekonomia wspótdzielenia (sharing cono3.0 jest tak zwana ekcono my). Ró wiez w tym ceczosi wychodza progranisci. Aplkacje mobilne, takie jak Car2go (Thln 5 mo pobran), DriveNow Carshering (100tys-500tys pobran), Traficar (50tys-100tys pobran)' ${ }^{2}$ pozwalaja na korzystanie $z$ carsharingu, ktory w coraz bardziej dynamiczny sposob wchodzi do europejskich miast. Wspołdzielenie samochodów pozwalające ograniczyć ilość aut na ulicach, szczególnie odciążające parkingi. Mamy tu do czynienia z krótkoterminowym wynajmem. W większości systemów na świecie, najkrotszy czas, na ktory možna wypożyczyć samochod to 15 minut. Auta mają wbudowany nadajnik GPS dzięki ktoremu z latwoscią można zlokalizować najbliższy wolny samochood. Samochód (np. w działającej w Krakowie firmie Traficar (il. 2)) otwiera się za pomocą aplikacji. Za pomocą smartfonu sczytujemy QR kod umiejscowiony na karoserii. W schowku znajdują się kluczyki do auta. Opłata za sensors, has opened the first Smart Parking. The application will lead a user to a free parking space this end sensors the size of a wallet ha fee. To placed in the asphalt, which, after a car has ridden over them, signalise that the spot has been taken. The system has been based on the widely known scheme of highlighting the availability of parking spaces with green and red lights over a given pourists in prticular, although some residert for surely appreciate it, is the ability to find one's car thanks to the tracking of individual parking spaces through a smartphone application.

After reaching a parking spot, the challenge shifts to finding a parking meter and paying for the parking time. Again, we are aided by mobile applica
tions, for instance by skycash, which operates in most Polish cities (see phot. 1). It allows us to conveniently pay a fee for using a paid parking zone, in addition to paying exactly the amount that reflects our parking time. Using a single application From the perspective of a city, the lowering of the costs of maintaining traditional parking meters is a significant factor, as the cost of the maintenance of one over a period of 10 years exceeds the cos of the device's purchase. This solution also allows age occupation of parking spaces in the various paid parking zones. There are attempts to make better use of existing parking spaces, for instance through the introduction of spaces with limited parking time or by making decisions to built underground parking lots.

In addition, applications that are used to pay parklic transport tickets. The aforementioned skycas applications offers such a service in over 40 urban centres all around Poland. In addition, a user can use it to pay for a cinema or train ticket, pay their bills or to buy insurance. Evidence of its popularloaded over 5 million times from the Google Play Store

One of the foundations of the functioning of a community within a Smart City 3.0 is the so-called sharing economy. Programmers are meeting the bile applications such as Car2go $(1 \mathrm{mln}-5 \mathrm{~m} / \mathrm{h}$ downloads), DriveNow Carsharing (100 thousand -500 thousand downloads), Traficar (50 thousand to 100 thousand downloads ${ }^{10}$ make it possible to participate in car sharing, which is more and sharing of cars allows the number of concurrent vehicles that are on the streets to be lower, particularly lessening the load on parking spaces. This is basically a short term rental. In most systems round the world, the shortest time that we can GPS tracker, which makes it easy to locate the closest free car. The car (for instance in the case of the Traficar company, which operates in Krakow - see phot. 2) can be opened with the use of the application. We use the smartphone to scan a QRcode on the car's body. The car keys are in the glove compartment. The fee for a single minute is like fuel and a parking fee in a paid parking zone. 
minutę użytkowania to kilkanaście groszy, zawiera w sobie juź wszystkie koszty lącznie z paliwem i oplatą za parkowanie $w$ strefie płatnego postoju. Wiele miast wspomaga tego typu inicjatywy, nauczone doświadczeniem miejskich wypożyczalni rowerowych, działających na podobnych zasadach, które sprawdziły się w wielu miejscach w Europie i na świecie. Doskonałym przykładem jest Paryż z Autolib (nazwa nawiazuje do miejskiej sieci wypożyczalni rowerowych Velib) gdzie władze ogłosity przetarg wart $60 \mathrm{mln}$ euro, który wygrata firma Vincenta Bolloré. Zwyciezca ma zapewnić funkcjo wanie 1100 stacji mieszczacych średnio po 6 samochodów wektryczych roulotowanych po calym Paryiu. Samochody te zostaly zaprojektowane w leger te zostaly za rozkentina odpowi zaprojekn Ferrari czy Maserati. Roczny abonament 144 euro za rok plus koszt za por godziny uzy kowania wynoszacy okolo 5 euro, wydaje się atrakcyjną ceną. Na podobne rozwiązanie zdecydowal się Berlin z programem Multicity stworzonym wraz z firmą Cltroen, Kora dostarczyla elektryczne samochody. Odwrotnie niz w Paryzu, postawiono na gotowy model francuskiego producenta C-Zero. W obu przypadkach większośc niezbędnych formalności zalatwić možna za pomocą aplikacji zainstalowanych w urządzeniu mobilinym. Dodatkowo aplikacja zbierze dane, pozwalające na rozbudowę systemu i rozbudowę stacji tam gdzie to niezbędne. Pojazdy te mogą często liczyc na dodatkowe przywileje $w$ postaci zarezerwowanych miejsc postojowych, czy też możliwości jazdy w strefach niedostępnych dla "cywilnych" aut.

Alternatywnym sposobem ułatwienia mieszkańcom poruszania się po mieście, są miejskie wypożyczalnie rowerów. Działają na tej samej zasadzie co carsharing, ale są znacznie bardziej przyjazne dla środowiska. Podobnie jak w wypadku samochodów, wypożyczenia dokonujemy za pomoca mobilnej aplikacji (Velib-Paryż, Wavelo-Kraków (il. 3) Veturilo-Warszawa i wiele innych). W wielu miastach pierwsze minuty sa oferowane dla użytkowników za darmo. Czesto czas ten pozwala na pokonanie całej zaplanowanej trasy. Ma to na celu zachecenie coraz wiekszej liczby mieszkańców do korzystania z rowerów jako środka transportu zastępczego zamiast prywatnego samochodu. Każdy rower wyposażony jest w lokalizator GPS, przez co w latwy sposób można dowiedzieć sie gdzie znajduje sie najbliższy wolny jednoślad. Dodatkowo, analizujac kierunki przejazdów rowerowych, można ustalić gdzie sieć ścieżek rowerowych wymaga poszerzenia, a gdzie miasto może wstrzymać się z inwestycjami. Dla operatora sieci, można dać wskazówkę, gdzie konieczna jest rozbudowa stacji. Ciekawą aplikacją, dzięki której można skorzystać z wypożyczalni na całym świecie jest Nextbike. Rozliczenie następuje pomiędzy poszczególnymi operatorami bez czynnego udziadu klienta. Jest to spore ułatwienie, szczególnie dla osób, które dużo podróżują.

Kolejnymi, upraszczającymi poruszanie się po miescie za rozsądną cenę aplikacjami, są te w rodzaju: Uber czy Mytaxi. Choc w załozeniach biznesowych cięzko doszukac się odwołań do Smart City 3.0, to jednak, dzięki możliwości kojarzenia kierowców z pasażerami wpisują się w ten trend. Pozwalające w szybki sposob zamówic taksówkę lub osobę świadcząca
Many cities support these types of initiatives due to the experience they have gained operating city ples and thats, which operate using similar principlaces in Europe and around the world A perfect example of this is Paris with its Autolib (the name is a reference to the municipal bicycle rental service called Velib), where the municipal authorities had organised a tender for a contract worth 60 millio euro, which was won by the company of Vincen 1100 stations which can be occupied by, on average, 6 electric cars each, to be located all around Paris. These cars were designed by the legendary Pininfarina design company, which had developed the body designs of cars such as Ferrari or Maseof a half-hour parking fee, which is around 5 couro, which appears to be a reasonable price. Berlin has decided to implement a similar solution in the form of the Multicity programme developed with Citroen Which provides electric cars. D ferenly than in Parcar model by the French car company, the existing In both cases, the majority of the necessary formalities can be taken care of using applications installed on a mobile device. An additional application is going to gather data making it possible to expand the system, as well as to set up stations in places in can also enjoy additional privileges in the form of reserved parking spaces or the right to travel in areas where "civilian" cars are not allowed.

An alternative form of making it easier for residents to travel around a city are municipal bicycle rentals. but are much friendlier to the environment Similarly to the case with cars, we rent a bicycle with the use of a mobile application (Velib - Paris, Wavelo - Krakow, see phot. 3, Veturilo - Warsaw and many othfree, Often this is enough time to of minutes are leee. Often, his is enough time to travel the entire age a larger amount of residents to use bicycles as a means of alternative transport to the car. Every bicycle is equipped with a GPS tracker, which makes it easy to see where the nearest free bicycle is located. In addition, by analysing the directions of network needs to be expanded and where the city can halt its projects for the time being. It can also be an indicator for the network operator regarding where additional stations are needed. An interesing application that makes it possible to use bicycle performed between individual operators without the active participation of the client. It is a considerable convenience, especially for persons who travel a lot. Additional applications that make it possible to travel around a city for a reasonable price are come in find references to the Smart City 30 model in their business models, they support this trend due to providing the ability to connect drivers with passengers. They allow to quickly order a taxi or a person who performs transport services to the location of tourists and the residents of enormous agglomerations, who do not need to know all the street names in a city. In addition, they are provided with informa-

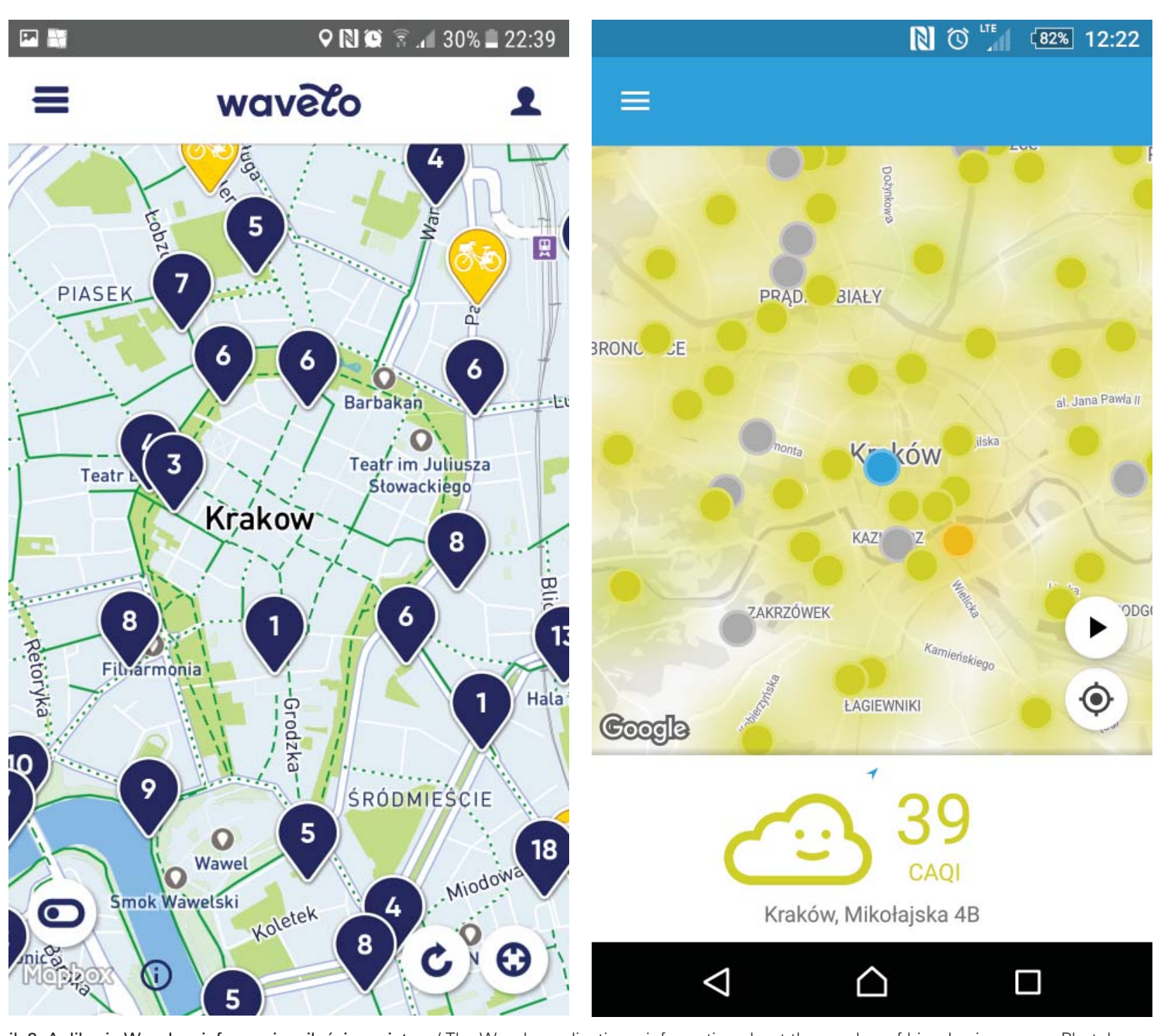

il. 3. Aplikacia Wavelo - informacija o ilóści powietraa / The Wavelo application - information about the
the authorphot The Airly application - infor pation about current air pollution levels. Phot. by the autho
i. 4. Aplikacia Airly - informacia o stanie rowerów w okolicy. Foto. Autor

usługi transportowe, której lokalizację pokazuję nasz telefon. Jest to duze ułatwienie zarówno dla turystów jak i mieszkańców ogromnych aglomeracji, którzy nie muszą znać wszystkich ulic w mieście. Dodatkowo dostaja informacje na temat przebiegu trasy oraz przybliżonej cenie przejazdu. Całość ransakcii odbywa się bezgotówkowo, co pozytywnie wpływa na bezpieczeństwo zarówno pasażerów jak i kierowcy. Dodatkowym atutem jest uniknięcie, często uciążliwej, konieczności dodzwonienia się na centrale, gdyż każdy użytkownik sam wizi czy i grzie sa dostep zne wone san pry aplikaci mosina midac, że zastosowáćn dom lub mieszkańcom, ale może posłużyć do optymalizacji kosztów prywatnych firm.

ŚRODOWISKO I OCHRONA ZDROWIA

Inną dziedziną gdzie widać gwałtowny rozwój rynku aplika-

cji mobilnych jest sektor ochrony srodowiska oraz zdrowia. tion regarding the length of a route and an approximation of the driver's fee. The entire transaction is he safety of both passengers and drivers. Another able necessity to connect to a taxi booking phone service, as every user can see if there are cars in the rea and if there are, their location. This example perfectly shows that the implementation of the idea of the Smart City and mobile applications can bring also serve as a means of optimising the costs of private businesses.

HEALTHCARE AND THE ENVIRONMENT Another field in which the rapid development of the context of urban planning of particular imp. In tance is the segment that is meant to make it easier for sick and disabled residents to move around a city without barriers. performed electronically, which positively affects An 
W kontekście urbanistycznym szczególnie ważny jest ten jego segment, ktory na celu ma ułatwienia chorym i niepełnosprawnym mieszkańcom poruszanie się bez barier po mieście.

Problemem nękającym miasta na całym świecie, w Polsce zaś szczególnie w miesiącach zimowych, jest smog. Nie bez wpływu na jego wystepowanie sa tu opisane wcześnie problemy komunikacyine. Czesto mieszkańcy nie zdaja sobie sprawy, jakim powietrzem aktualnie oddychaja. Polskie przepisy sa w tym wypadku wyjatkowo libelo. Polskie przedać to przy poŕm 10 . W poziomów alarmowych da pytów cać za to przy porow w muje sie sężnie wy W Pące $300 \mu \mathrm{p} / \mathrm{m}$, w sasiednich Czechap (ii. 4), zalozony przez krowsich studentow, poztar-

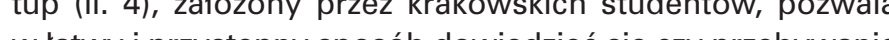
what i przystempy sposób dowiedzié się czy przebywanie aktualnie na zewnąr jest bezpieczne dla zdrowia, czy też wręcz przeciwnie. Gęsta siec czujników pozwala wychwycic nie tylko aktualne zanieczyszzzenia, ale takze wskazac rejon skąd one pochodzą oraz kierunek ich przemieszczania. Informacje praktyczne mogą ułatwić życie osobom w podeszłym wieku oraz tym z chorobami układu oddechowego. Ciekawym rozwiązaniem jest oferowanie czujników kontrolujących jakość powietrza, zarówno instytucjom jak i osobom prywatnym. Dzięki temu siec punktów pomiarowych stale się rozrasta i pokrywa juz praktycznie cały obszar kraju. Nie byłoby to możliwe, gdyby nie oddolna inicjatywa mieszkańców, którzy zyskują niezbędne narzędzie do walki z zanieczyszczeniem powietrza. Oczywiście nie jest to jedyna firma, która udostępnia swoje oprogramowanie do sprawdzania jakości powietrza (podobą usługę oferuje: Air Quality, Kanarek -jakość powietrza czy Global Air Quality Index)11. Godnym odnotowania jest tu model funkcjonowania całego systemu. Stale powiększajacego sie dziekki aktywności mieszkańców w myś założeń Smart City 3.0.

Coraz więcej miast, $w$ przypadku wystąpienia smogu, oferuje darmowa komunikacie dla wszystich tych którzy postajodar wybré komuika zbiowa zamiast prywatnogo wia wy ${ }^{12}$. vidnośc

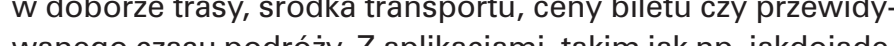

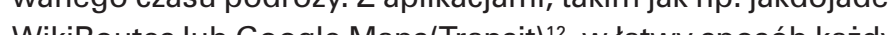

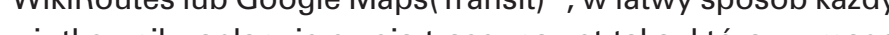
uzytkownk zaplanuje swoją trasę, nawet taka, kóra wymaga kiku przesiadek. Uzyk kownik orry nawe teraz inne informacje wprost do swojego smartfonu. Sama nawigacja opiera się na wskazaniu punku, do ktorego chceny się dostac, telefon z załączonym modułem GPS sam zlokalizuje pozycję usługobiorcy i wskaże najlepszą z możliwych tras do celu. Dzięki możliwości komentowania, aplikacje te stają się też platformą wymiany uwag, mogących pomoc osobom, które pierwszy raz znalazły się $\mathrm{w}$ danym mieście. $Z$ punktu widzenia władz miejskich, istotna jest możliwość optymalnego wykorzystania taboru, poprzez zminimalizowanie zbędnych podróży błądzących mieszkańców.

Bardzo ciekawy projekt mający na celu ułatwienie korzystania z przestrzeni miejskiej osobom z wadami wzroku oraz, jak się później okazało, także turystom, wprowadza Warsza-
One problem that plagues all cities around the world, particularly so during the winter months Polans, is smog. The abovementioned traffic problems are not without their influence on its appearcondition of the air that they are currently breathing Polish regulations are outstandingly liberal in this regard. This can be perfectly seen when comparin the alarm levels for PM 10 atmospheric particulate matter. In Poland, a concentration of $300 \mu \mathrm{g} / \mathrm{m}^{3}$ is
considered the alarm level, while in the neighboring Czech Republic it takes only $100 \mu \mathrm{\mu g} / \mathrm{m}^{3}$ for a state of alarm to be declared. Airly startup (phot. 4), founded by students from Krakow, allows us to easily and conveniently learn whether going out side is currently safe for our health or not. A dense only current pollution levels, but also point to the region from which it originates and the direction in which it moves. Practical information can make life easier for senior citizens, as well as for those with the offering of air quality sensors to institution is the offering of air quality sensors to institutions, as
well as individuals. This causes the sensor network which currently covers practically the entire area of the country, to expand. This would not be possible if not for the grassroots initiative of the residents, who are being given the necessary tool in the figh against air pollution. Of course, this is not the only
company that makes its software available in to assess air quality (a similar service is being of fered by: Air Quality, Kanarek - jakość powietrza o Global Air Quality Index)"1". Of particular note is the model of the functioning of the entire system, which is constantly expanding thanks to the activity of resMore and more cities offer free public transport to all persons who decide to choose public transpot instead of a private car in the event of $\mathrm{smog}^{12}$. For many car users, this choice creates a difficulty in sessing the ticket price or estimated travelt as With applications such as, for example, jakdojade WikiRoutes or Google Maps (Transit)'13 any user can easily plan their route, even one that requires multiple transfers. A user can access this data, as well as additional information, straight through their lecting a point to which we want to based on sephone, with an initiated GPS module, will locate the position of the user by itself and point to the best possible route to the target destination. Thanks to the option of commenting, the applications are can help persons who have found themselves a given city for the first time. From the point of view of municipal authorities, the ability to optimally use their transport fleet through the minimisation of redundant travel routes used by lost residents is of Considerable importance.

project which is aimed at making it easier to us urban spaces by persons with visual impairment and, as it has turned out, by tourists as well. Virtualna Warszawa is meant to help a person orientate themselves not only along streets, but also inside public buildings. It is based on GPS and a network and 400 thousand receivers, as well as smartphones that have the application installed. Persons wa. Virtualna Warszawa ma na celu pomoc w odnajdywaniu publicznej. Opiera się na GPSie, sieci beaconów (docelowo sieć ma liczyć od 200 do 400tys. odbiorników) oraz smartfonów z zainstalowaną aplikacją. Osobom słabo widzacym dzięki funkcji wybierania głosowego, pozwala odnaleźć się wewnatrz budynku, wskazać droge do właściwego urzednika, czy pobrać numerek w kolejce. O skali innowacyiności tego przedsiewziecia niech świadczy fakt, że Warszawa wygrał dzieki niemu konkurs Mayors Challange organizowany przez fzieki nych ośrodków miejkich. Stolica Polski otrzyma dodatko in$50 \mathrm{mln}$ zł z Unii Europejsk

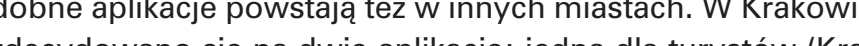

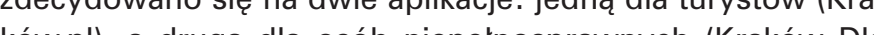

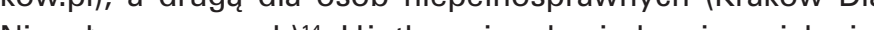
Niepelhosp kawostek o mieście, znajdą najbliższy sklep, restaurację czy tez toaletę. Niestety, nie umozilwiaja one zalatwienia spraw w urzędach, wśród mieszkańców.

\section{PODSUMOWANIE}

Wszystkie wymienione aplikacje oraz wiele innych, równie sta i jego funkcjonalnośc, czyniąc ją bardziej przyjazną i przystępną dla mieszkańców i turystów. Dzięki nim, „używanie miasta staje sie prostsze, a korzystanie z jego walorow duż latwiejsze. llosc uzytkownikow technologii mobilinych z roku na rok rośnie i będzie rosnąc $w$ dynamicznym tempie, co obrazuja dane z ostatnich lat. Smartfony stały sie swoistymi kluczami do współczesnych miast. Koniecznym stanie sie więc, uwzględnienie i wykorzystanie tego $\mathrm{w}$ ich kształtowaniu. W latach 2014-2020, z unijnego budżetu spójności Polska otrzyma ponad $10 \mathrm{mld}$ euro na inteligentny rozwój i cyfryzacje ${ }^{15}$. Daje to szanse aby proces tworzenia Smart City w polskich aglomeracjach jeszcze bardzie przy Siszyl. Bardzo waziny czynnikiem, który jest niezbedny do funkcionoczbie informacj aplikacji, które w szybki sposób dostarczają im przetworzonych danych, sa wstanie zmieniać swoje otoczenie. Pozwalaja na przywrócenia miasta osobom, które z różnych przyczyn zostały z niego wykluczone. Dają możliwość zadbania o zdrowie i środowisko. Ułatwiają przemieszczanie się po mieście. A wszystko to przy pomocy urządzenia, które waży mniej niż 200 gramów.

PRZYPISY

S. Kemp, Raport We Are Social I Hootsuite, Digital in 2017 Global Overview

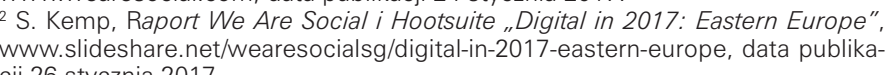

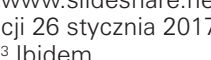

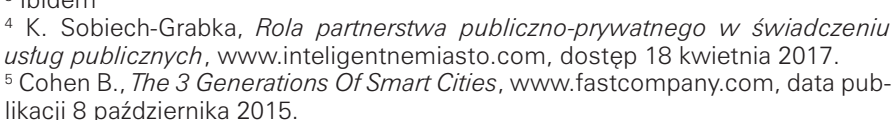
likaciji 8 páddziernika 2015.
6 B. Domniak, Smart City 3.0, wnw.inteligentnemiasto.com, dostęp 19 kwietnia
2017. with visual impairment, thanks to the function of issuing verbal commands, can orientate them selves inside a building, be pointed in the directio a line. The fact that Warsaw won the Mayors Chatlenge competition, organised by Michael Bloomberg's foundation, thus beating 150 other urban centres, shows the scale of this endeavour. The capital of Poland is also going to receive 50 millio mentation of this project ${ }^{14}$ S Similar applications aalso being developed in other cities. Krakow has opted for two applications, one for tourists (Krakow.pl), and another for disabled persons (Kraków Dla Niepełnosprawnych) ${ }^{15}$. Their users will be able to learn interesting facts about the city, locate th they will not make it possible to take care of official administrative matters, which would have surely increased their popularity among residents.

CONCLUSION

Al of the abovementioned applications, as well to define a city's space and its functionality anew making it friendlier and more convenient for residents and tourists. They make "using" a city much simpler, and partaking in its qualities a lo easier. The number of users of mobile technoloto do so at a dynamic pace, as data from recent years have shown. The smartphone has become a sort of key to a modern city. Thus it is becoming necessary to take this into account and make use of it in its shaping. Poland will receive $10 \mathrm{bl}-$ sation from the European Integrity Fund in the years 2014-202016. This provides an opportunity for the process of establishing Smart Cities in Polish agglomerations to increase its pace even
more. Active residents, the number of which is rising each day, are a very important factor that is to the larger and larger amount of information and applications that can quickly provide it with processed data, they are able to change their surroundings. They allow the city to be reclaimed by cluded from it. They provide the ability of protecting our health and our environment. They make it easier to travel around a city. And all of this thanks .

ENDNOTES:

KS. Kemp, Raport We Are Social i Hootsuite, ,Digital in 2017
Global Overview" www.wearesocial.com, published on the 24th of January 2017. . Are Social i Hootsuite "Digital in
2 S. Kemp, Raport We A

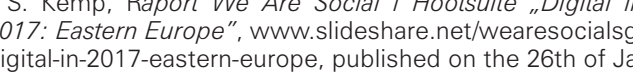
nuary 2011.7
3 J bidem

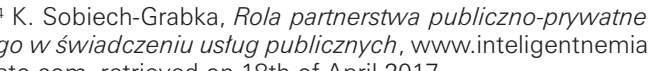

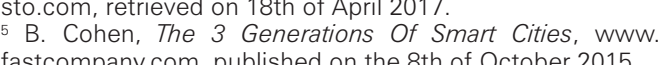
fastcompany.com, published on the 8th of October 2015 .
6 B. Domnia, Smart City 3.0, www.inteligentnemiasto.com retrieved on, the 19th of April 2017 .
P. Grabiec, Smart cities $w$ prakty

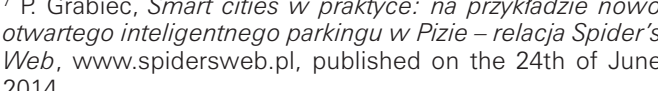


7 P. Grabiec, Smart cities w praktyce: na przykładzie nowo otwartego inteligentnego parkingu w Pizie - relacja Spider's Web, www.spidersweb.pl data publikacji 24 czerwca 2014

${ }^{8}$ P. Grabiec, Te funkcje docenią wszyscy kierowcy. Google powie, czy tam gdzie jedziesz sa wolne miejsca parkingowe, www.spidersweb.pl, data publikacji 17 stycznia 2017.

${ }^{9}$ Stan na dzień 5 kwietnia 2017 za play.google.com

${ }^{10} \mathrm{lbidem}$

11 Ibidem

12 D. Kosiński, Smog w całej Polsce! Jutro w trzech miastach komunikacja miejska bedzie darmowa, www.spidersweb.pl, data publikacji 8 stycznia 2017.

${ }^{13}$ play.google.com

14 W. Karpieszuk, Rewolucyjna aplikacja na smartfony dla Warszawy. Mapa i przewodnik, www.warszawa.wyborcza.pl, data publikacji $31 \mathrm{mar}$ ca 2015.

15 www.krakow.pl/aplikacje/199948,artykul,krakow_dla_niepelnosprawnych.html, dostęp z dnia 20 kwietnia 2017

${ }_{16} \mathrm{~S}$. Bień-Chudarek, Smart City - czym jest inteligentne miasto i z jakich czynników się składa, www.gomobi.pl, data publikacji 23 lipca 2015.

\section{LITERATURA}

[1] Kemp S., Digital in 2017 Global Overview, Raport We Are Social i Hootsuite, www.wearesocial.com, 24. 01. 2017.

[2] Kemp S. Digital in 2017: Eastern Europe, Raport We Are Social i Hootsuite, www.slideshare.net/wearesocialsg/digital-in-2017-eastern-europe, dostęp 10. 04. 2017.

[3] Sobiech-Grabka K., Rola partnerstwa publiczno-prywatnego w świadczeniu usług ublicznych, www.inteligentnemiasto.com, dostęp 18. 04. 2017

[4] Cohen B., The 3 Generations Of Smart Cities, www.fastcompany.com, dostęp 10. 04. 2017

[5] Domniak B., Smart City 3.0, www.inteligentnemiasto.com, dostęp 19.

04. 2017.

[6] Grabiec P., Smart cities w praktyce: na przykładzie nowo otwartego inteligentnego parkingu w Pizie - relacja Spider's Web, www.spidersweb. pl, dostep 19. 04. 2017

[7] Grabiec P., Te funkcję docenią wszyscy kierowcy. Google powie, czy tam gdzie jedziesz są wolne miejsca parkingowe, www.spidersweb.pl, dostep 17. 04. 2017.

[8] Kosiński D., Smog w całej Polsce! Jutro w trzech miastach komunikacja miejska będzie darmowa, www.spidersweb.pl, dostęp 7. 04. 2017.

[9] Karpieszuk W., Rewolucyjna aplikacja na smartfony dla Warszawy. Mapa i przewodnik, www.warszawa.wyborcza.pl, dostęp 7. 04. 2017.

[10] Bień-Chudarek S., Smart City - czym jest inteligentne miasto i z jakich czynników się składa, www.gomobi.pl, dostęp 6. 04. 2017.
8. Grabiec, Te funkcje docenia wszyscy kierowcy. Google powie, czy tam gdzie jedziesz sa wolne miejsca parkingowe, www.spidersweb.pl, published on the 17th of January 2017.

${ }^{9}$ Statistics for the 5th of April 2017 by play.google.com

${ }^{10}$ Ibidem

11 lbidem

12 D. Kosiński, Smog w całej Polsce! Jutro w trzech miastach komunikacja miejska bedzie darmowa, www.spidersweb.pl, published on the 8th of January 2017.

${ }^{13}$ play.google.com

14 W. Karpieszuk, Rewolucyjna aplikacja na smartfony dla Warszawy. Mapa i przewodnik, www.warszawa.wyborcza.pl, published on the 31st of March 2015

15 www.krakow.pl/aplikacje/199948,artykul,krakow_dla_niepelnosprawnych.html, retrieved on the 20th of April 2017

${ }^{16} \mathrm{~S}$. Bień-Chudarek, Smart City - czym jest inteligentne miasto i z jakich czynników się składa, www.gomobi.pl, published on the 23rd of July 2015

\section{BIBLIOGRAPHY}

[1] Kemp S., Digital in 2017 Global Overview, Raport We Are Social i Hootsuite, www.wearesocial.com, 24. 01. 2017.

[2] Kemp S., Digital in 2017: Eastern Europe, Raport We Are Social i Hootsuite, www.slideshare.net/wearesocialsg/digital-in2017-eastern-europe, dostep 10. 04. 2017.

[3] Sobiech-Grabka K., Rola partnerstwa publiczno-prywatnego w świadczeniu usług ublicznych, www.inteligentnemiasto.com, dostęp 18. 04. 2017.

[4] Cohen B., The 3 Generations Of Smart Cities, www.fastcompany. com, dostęp 10. 04. 2017.

[5] Domniak B., Smart City 3.0, www.inteligentnemiasto.com, dostęp 19. 04. 2017

[6] Grabiec P., "Smart cities w praktyce: na przykładzie nowo otwartego inteligentnego parkingu w Pizie - relacja Spider's Web, www. spidersweb.pl, dostęp 19. 04. 2017.

[7] Grabiec P., Te funkcje docenia wszyscy kierowcy. Google powie, czy tam gdzie jedziesz są wolne miejsca parkingowe, www. spidersweb.pl, dostęp 17. 04. 2017

[8] Kosiński D., Smog w całej Polsce! Jutro w trzech miastach komunikacja miejska będzie darmowa, www.spidersweb.pl, dostęp 7. 04. 2017.

[9] Karpieszuk W., Rewolucyjna aplikacja na smartfony dla Warszawy. Mapa i przewodnik, www.warszawa.wyborcza.pl, dostęp 7. 04. 2017.

[10] Bień-Chudarek S., Smart City - czym jest inteligentne miasto i z jakich czynników się składa, www.gomobi.pl, dostęp 6. 04. 2017. 